\title{
Rediscovery of an "extinct" fly Adapsilia coarctata Waga, 1842 (Diptera: Pyrgotidae) in Poland
}

\author{
Przemysław TROJAN
}

Museum and Institute of Zoology, Wilcza 64,00-679 Warszawa; e-mail: trojan@miiz.waw.pl

\begin{abstract}
Adapsilia coarctata Waga is recorded from SE Poland on xerothermic habitats in Nida Valley in the year 1952. The data on occurrence of Adapsilia coarctata Waga in Europe in $20^{\text {th }}$ century have been gathered. The problem of extinction of the species in Central Europe is discussed.
\end{abstract}

Key words: Adapsilia coarctata, Diptera, Pyrgotidae, record, Poland

In 1842 Polish naturalist A. Waga found on the shrub of an oak near Warsaw an unknown fly of extraordinary appearance. He described it as a new genus and species - Adapsilia coarctata Waga. Twelve years later another specimen was found in Złoty Potok near Częstochowa (Waga 1857) and then in the valley of the Świder river near Wiązowna (Sznabl 1881).

Analysis of the data on the occurrence of Adapsilia coarctata Waga lead the authors of the Polish Red List of Animals (Palaczyk et al. 2002) to the suggestion that this species was probably extinct in the 19th century in Central Europe. The aim of this communication is to correct that view.

In the collection of the Museum and Institute of Zoology PAS Adapsilia coarctata Waga is represented by two females (Fig. 1) caught 30 Aug 1952 in the Nida river valley in Krzyżanowice, Pińczów distr. (Małopolska Upland). This region has many xerothermic habitats and associated thermophilous fauna.

Both specimens are equal in body length $(9 \mathrm{~mm})$ and wing length $(9.5 \mathrm{~mm})$. Their description does not indicate great differences as compared to that given by Hendel (1933). Body and its appendages are yellow. Abdomen of six visible segments low fixed in thorax. Last tergite downward curved horn-like more than two times longer than preceding segments (Fig. 2). Hind margins of tergites strongly setulose except last tergite. Two basal tergites long narrow at the base expanding toward the end, where the second is two times broader than at the base (Fig. 3). Four following segments very short. Head stretched out in the point of the insertion of antennae (Fig. 4). Distinct facial keel extending from the base of antennae to the peristome separates two shallow grooves. Genae with brown spot on the lower margin of the eye. Mouth retractive, palpi uniarticulate, flat, slightly curved, rounded at the tip, with some dark setulae (Fig. 4). Antenna yellow, arista with pubescence a little longer than antennae(Fig. 4). Wings a little milky tinted with yellow veins (Fig. 5).

Trojanowa (1956) gives some data on the occurrence of Adapsilia coarctata Waga in Austria and Italy. The flies have also been found in West Ukraine (Stackelberg 1970). More detailed data on the distribution of this species can be found in A. Soós (1984). It has been found in Austria, Italy, Hungary, Switzerland also in Central and South Russia and in the Far 
East, Asia and Mongolia. Two years ago Nartshuk \& Korneev (2005) reported it from Belarus in Mogilovskii district.
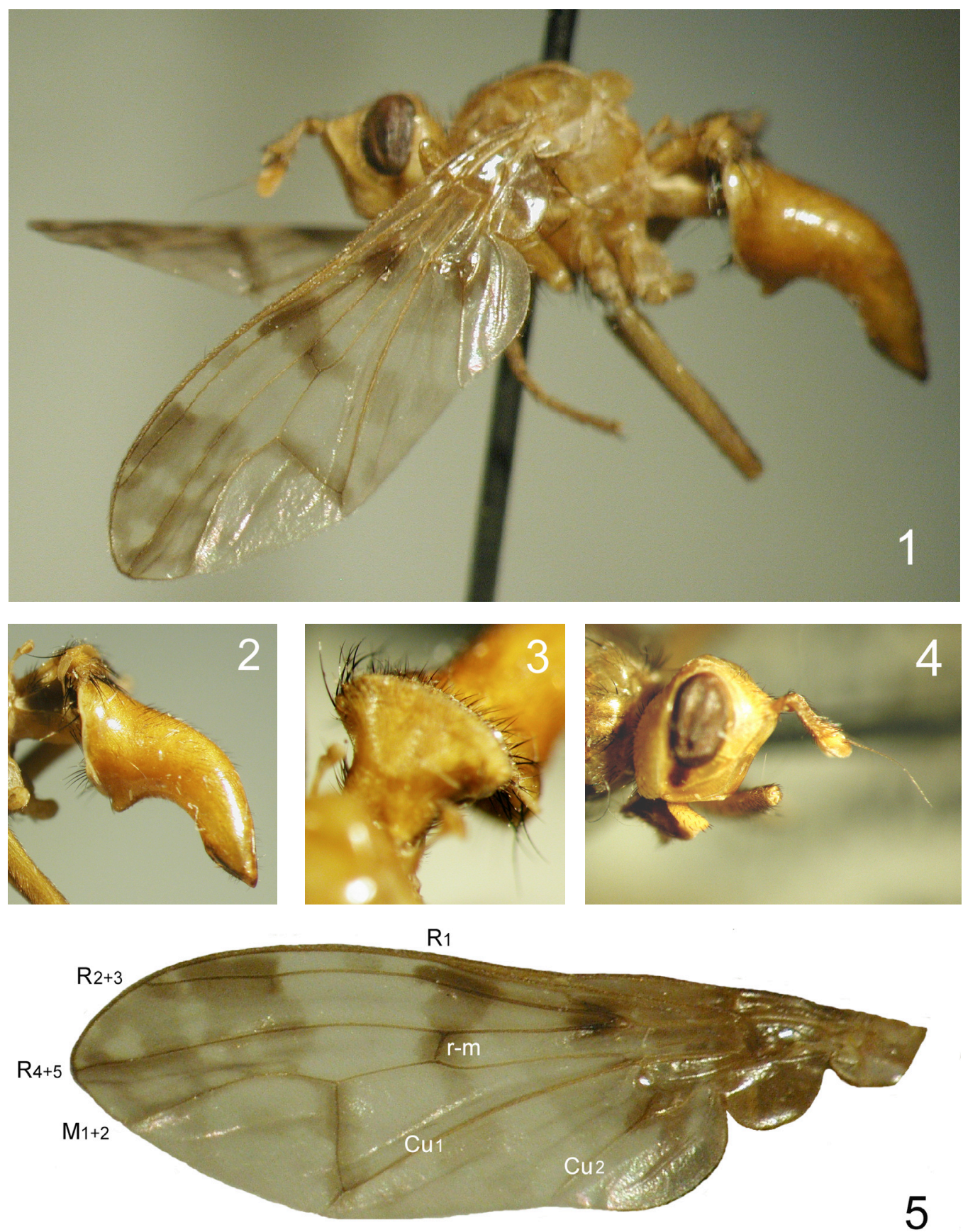

Figs 1-6. Adapsilia coarctata Waga, females from Krzyżanowice (Nida Valley); 1 - specimen in side-view, 2 abdomen, 3 - basal tergite, 4 - head with antenna, in profile, 5 - wing. 
Most specimens in Europe were collected in $19^{\text {th }}$ century chiefly in Alps: Austria (Franz 1989), Switzerland (Merz 1996), Italy (Rondani 1870) but also in Hungary (Soos 1943), near Wien in Austria (Handlirsch 1886), Belarus (Nartshuk \& Korneev 2005) and Poland. In the $20^{\text {th }}$ century $A$. coarctata Waga was caught three times in Europe: in Nord-East Alps (Oberweiden, 24.08.1917), in Northern Caucasus (1\%, Yessentuki, 15.11.1926) (Nartshuk \& Korneev 2005) and in Poland. The period of occurrence of Adapsilia coarctata Waga lasts from May to November and freshly hatched specimens were found in May, June and September. Most of the flies caught were single specimens (15 occasions), a catch of two specimens was reported only 5 times, and more than two only rather exceptionally.

Adapsilia coarctata Waga has a cryptic mode of life. It is rarely collected in nature. The greatest number of specimens in Europe were caught near Wien (Handlirsch 1886). However Handlirsch states that all they were freshly hatched specimens. The same opinion can be found in the description of the species by A. Waga (1842). It is a rather nocturnal species that can sometimes be attracted to light; both specimens from Krzyżanowice were caught in light traps. It does not visit flowers and therefore it is very rare in collections.

Its occurrence in the 20th century in Poland is thus confirmed. It can be surely excluded from the list of extinct species in Poland.

\section{ACKNOWLEDGMENTS}

The author would like to thank to Prof. Dr Agnieszka Draber-Mońko and Prof. Dr Ryszard Szadziewski for their valuable remarks to the manuscript. Completing the data and references for this paper would have be impossible without the kind help of Prof. Dr L. Papp, Prof. Dr V. Sidorenko and Dr E. P. Narchuk. Special thanks are directed Dr Jolanta Wytwer for her help in preparing the figures. I wish to express my thanks also to Dr Mariusz Górnicz who reviewed the manuscript of this paper correcting the language.

\section{REFERENCES}

FRANZ H. 1989. Nie Nordost-Alpen im Spiegel ihrer Landtierwelt. 6. 2. Diptera, Cyclorapha. Universitätsverlag Wagner, Innsbruck, $446 \mathrm{pp}$.

HANDLIRSCH A. 1886. Über die Hymenopteren und Dipteren der Türkenschanze bei Wien. Verhandlungen des zoologisch-botanischen Gesellschaft in Wien 36: 33-36.

Hendel F. 1933. Pyrgotidae. In: LindNER E. (ed.), Die Fliegen der Palaearktischen Region, E. Schweizerbart'sche Verlagsbuchhandlung (Erwin Nägele), Stuttgart, 36: 1-15.

Merz B. 1996. Zur Faunistik der Pyrgotidae, Platystomatidae und Ulididae (=Otitidae) (Diptera, Tephritidae) der Schweiz mit spezieller Berücksichtigung von Otites Latreille. Mitt. Schweiz. ent. Ges. 69: 405-416.

NartshuK E. P. \& KorneeV V. A. 2005. Data on the fauna of Pyrgotidae (Diptera, Cyclorrhapha) of the Russian Far East. Far Eastern Entomologist 147: 1-10.

PalaczyK A., Soszyński B., Klasa A., Bystrowski C., MikolajczyK W. \& Krzemiński W. 2002. Diptera Muchówki. In: GŁOWACIŃSKI Z. (ed.), Polish Red List of Animals. Invertebrates, pp. 38-44. Institute of Nature Protection PAS, Kraków, 156 pp.

RONDANI C. 1870. Ortalidinae italicae colectate, distinctae et in ordinem dispositae. Dipterologiae Italicae prodromus, 7 (1): 161-188.

Soós S. A. 1943. Új legycsalád a Magyar faunában. Folia entomologica hungarica 8 (104): 94-96.

Soós S. A. 1984. Family Pyrgotidae. In: Soós S. A. \& PAPP L. (eds.), Catalogue of Palaearctic Diptera. MicropezidaeAgromyzidae. Vol. 9, pp. 36-38. Akadémiai Kiadó, Budapest, 460 pp.

Stackelberg A. A. 1970. 58. Sem. Pyrgotidae. In: Bej-Bienko G. Ya. (ed.), Opredelitel nasekomych evropejskoj casti SSSR. Nauka, Leningrad, 5, 2: 120-121.

SZNABL J. 1881. Spis owadów dwuskrzydłych zebranych w Królestwie Polskim i Gubernii Mińskiej. Pamiętnik Fizjograficzny, Warszawa, 1: 357-390.

Trojanowa R. 1956. Conopidae, Pyrgotidae. In: JACZEWSKI T. (ed.), Klucze do oznaczania owadów Polski, 28 Muchówki - Diptera, 35-36. PWN, Warszawa, 44 pp.

WAGA A. 1842. Adapsilia genre de Diptères apartenant a la sous-tribu Dolichocères de Macquart, voisin de Sepedon et Tetanocera. Annales de la Société entomologique de France 1: 279-282. 
WaGA A. 1857. Sprawozdanie z podróży naturalistów odbytej w r. 1854 do Ojcowa (Dokończenie). Biblioteka Warszawska, Nowa Seria, 2: 161-227.

\section{STRESZCZENIE}

[Odkrycie „wymarłej” muchówki Adapsilia coarctata Waga (Diptera: Pyrgotidae) w Polsce]

Opisana w XIX w. przez Antoniego Wagę muchówka o niezwykłej budowie, Adapsilia coarctata, została uznana w Polskiej Czerwonej Liście Zwierząt za wymarłą w Europie Środkowej w XIX w. Po przeanalizowaniu danych o liczebności i występowaniu tego gatunku w Europie w XX w. autor przyjął, że jest to gatunek o ukrytym trybie życia i dlatego jest odławiany bardzo rzadko. Dane o jego występowaniu nie potwierdzają przypuszczenia, że jest to gatunek wymarły.

Accepted: 20 April 2007 